\title{
The Vital Role of Gender Diversity on Corporate Outcomes: The Need for Empirical Studies Concerning Frontier Markets
}

\author{
Hauwa Daniyan Bagudu \\ Department of Banking and Finance \\ The Federal Polytechnic Bida, Niger State \\ Tel: 23-480-6244-1337_E-mail: hauwadaniya@yahoo.com
}

\begin{abstract}
Badru, Olayemi Bazeet (Corresponding Author)
School of Economics, Finance and Banking (SEFB) and Othman Yeop Abdullah Graduate School of Business (OYAGSB), Universiti Utara Malaysia, Sintok, Kedah, Malaysia
\end{abstract}

Tel: 60-14-726-5986_E-mail: bazeetolayemi@gmail.com.

\author{
Abdulmumini Baba Alfa \\ Department of Economics \\ Ibrahim Badamasi Babangida University Lapai, Niger State \\ Tel: 23-470-1192-5695Ｅ-mail: balfa80@gmail.com
}

Received: Oct 8, 2015 Accepted: Nov. 23, 2015 Published: December 1, 2015

doi:10.5296/ajfa.v7i2.8404 URL: http://dx.doi.org/10.5296/ajfa.v7i2.8404

\begin{abstract}
The purpose of the study is to review empirical studies related to gender diversity on corporate outcomes and suggest the need for more empirical research on gender diversity in frontier markets. Several empirical studies have identified the need for a critical mass of female directors and executives in corporate firms. This review further justifies the clamour for more female representation on boards globally. Nigeria is a country that has very weak corporate governance compared to the United States (US) and other developed countries. Therefore, the
\end{abstract}


present study suggests that more empirical studies in this area should be carried out and widely explored. It is hoped that capital market regulatory authority can consider the need for $35 \%$ women in public institutions and corporate settings. In other words, there is an urgent need for the implementation of this policy as this would have implications for women's development and career planning.

Keywords: Gender diversity, Corporate governance, Corporate outcomes, NEEDS, Nigeria 


\section{Introduction}

The Board of Directors is expected to act in the best interests of shareholders by advising, monitoring, managing and ensuring that the management is responsible for their actions and decisions. The board takes appropriate action to reduce the agency problems that may likely exist between the shareholders and the management. As such, the structure of the board is an important corporate governance mechanism for a company's financial success and the society in which it operates (Gamba \& Goldstein, 2009; Johnson, Schnatterly, \& Hill, 2012; Rose, 2007; Thiruvadi \& Huang, 2011).

The large number of corporate scandals and failures as well as crisis around the world over the last decade, such as Enron, WorldCom, HealthSouth Corporation, Global Crossing and the 2007/2008 financial crisis, have raised substantial concern about the effectiveness of the corporate governance system. This is because the events have adversely affected the global economy and diminished investors' confidence on the reliability of financial information provided by companies. As a result, capital market regulators and academic researchers from different fields, like accounting, finance and management, are of the opinion that these events could have been prevented if a considerable number of women ran the affairs of the companies (Ferreira, 2015; Sherwin, 2014; Seierstad, Warner-Søderholm, Torchia, \& Huse, 2015).

For instance, Liu, Wei, and Xie (2014) reported that Christine Lagarde (IMF Managing Director) viewed that the Lehman Brothers' corporate scandal could have been averted if Lehman Brothers had been Lehman Sisters! Moreover, a considerable number of scholars have suggested that gender diversity matters for company level outcomes, board cognition, dynamics and decision-making tasks (Johnson et al., 2012; Thiruvadi \& Huang, 2011). This is due to the fact that women listen more to corporate executives, act diligently, are risk averse, do not engage in herd-like behaviour and are more cautions when deciding on corporate decisions (Liu et al., 2014; Sherwin, 2014; Thiruvadi \& Huang, 2011). In terms of corporate financing decisions, female directors are known to be very cautious and determined to equip the company they manage with sufficient resources that can improve its growth and survival (Adams \& Funk, 2012; Capezio \& Mavisakalyan, 2015; Huang \& Kisgen, 2013; Levi et al., 2014). Similarly, some other scholars have suggested that the presence of female directors on the board of directors strengthens corporate governance through effective monitoring and creating a more transparent and informative environment that can enhance public confidence (Terjesen et al., 2015; Thiruvadi \& Huang, 2011; Upadhyay \& Zeng, 2014).

All these suggest that a diverse board may be likely to affect corporate outcomes. On this basis, this study reviews relevant literature on how gender diversity is related to corporate outcomes. This study further suggests the need for more empirical evidence concerning the impact of gender diversity on various corporate outcomes. This is because existing literature on gender diversity has been conducted in mature markets, like the United States (US) and Europeans markets, with little empirical studies in Asia and Africa, particularly Nigeria. Campbell and Minguez-Vera (2008) illustrated that gender composition of the board can serve as a very important internal control mechanism, especially in countries where the external control 
mechanism is less developed. Therefore, considering the inadequacy of a regulatory infrastructure for the implementation of corporate governance mechanisms, as well as a series of corporate failures in financial and non-financial sectors in Nigeria, it is felt that gender diversity can serve as a crucial factor for the implementation of good corporate governance practices in Nigeria (Edward, Angaye, \& Gwilliam, 2008). However, in Nigeria, the corporate governance mechanism does not include a code on gender diversity. On this note, the study suggests that more gender-related studies should be conducted on various corporate outcomes. The remainder of the paper is organized as follows: Section 2 discusses the global trend of gender diversity, followed by the section 2.1 on gender policy issue in Nigeria. Then section 3 focuses on theoretical discussion, while section 4 presents empirical studies on gender diversity on various corporate outcomes, and finally section 5 concludes the study.

\section{Gender Diversity Trend}

Gender diversity is an area of corporate governance research that has taken centre stage in the global arena to enrich corporate life and to empower the economy. Board gender diversity is an important corporate governance mechanism that affects a company's financial outcomes (Terjesen et al., 2015), besides enhancing board governance and monitoring effectiveness (Capezio \& Mavisakalyan, 2015). For example, Mohan (2014) claimed that female Chief Executive Officers (CEOs) serve mostly in innovative and team-building industries that require collaborative behaviour. In addition, Schwartz-Ziv (2013) asserted that a higher number of women in attendance at corporate board meetings increase the length of discussion in meetings. As such, a gender-balanced board is more active as members possess a wide and diverse set of skills.

Owing to the importance of gender diversity globally, various policy initiatives on gender balance on corporate boards have been carried out by regulators in different countries, such as the US, the European Union, Australasian and Asian (Vietnam, Malaysia, and China) countries (Goergen \& Renneboog, 2014; Nguyen, Locke, \& Reddy, 2015). In countries like the US, the United Kingdom (UK), Australia and Germany, public listed companies are mandatorily required to report in proxy statement whether the nominating committee considers gender diversity when nominating board members (Capezio \& Mavisakalyan, 2015; Reguera-Alvarado, de Fuentes, \& Laffarga, 2015). Meanwhile, other countries, such as Norway, Spain, France, Netherlands and Italy, legally require at least $40 \%$ of the board members to be female (Reguera-Alvarado et al., 2015), while in Malaysia, it is $30 \%$ female members on the board. This initiative has seen an increase in the number of women, both in the government and corporate entities. For example, Ferreira and Gyourko (2014) documented that unlike the 1970 s, where only $2 \%$ of women participated and won in local government elections, the percentage increased to more than $15 \%$ in 2005 . Similarly, Farrell and Hersch (2005) documented that the percentage of board seats held by women increased from $6 \%$ to $12 \%$ between 1990 and 1999; while it was $87 \%$ for a sample of 300 unregulated fortune 1,000 companies in 1999. Huang and Kisgen (2013) showed an increase in the number of female top executives in the US in 1994 from $3.0 \%$ of women Chief Finance Officers (CFOs) and $0.5 \%$ of women CEOs to $7.5 \%$ of women CFOs and $1.5 \%$ of women CEOs in 2005 . In addition, compared to $0.2 \%$ of female CEOs on fortune 500 companies in 
1992, Mohan (2014) reported that over 5\% of Standard \& Poor's (S\&P) 1,500 companies and $4 \%$ of the fortune 500 were led by women CEOs. Similarly, Masta and Miller (2011) noted that $6 \%$ of women are in the top executive rank of US companies. Reguera-Alvarado et al. (2015) revealed that the increase in the number of female directors was over $98 \%$, using a sample of 125 public listed companies on the Madrid Stock Exchange between 2005 and 2009. Nevertheless, the increase in the number of female representation is still very low. This is worth noting as almost half of the world's population comprise women and they control about $80 \%$ of the household spending decisions (Shervin, 2014).

\subsection{Issues Related to Gender Policy in Nigeria}

As of January 2015, Nigeria has a population size of 51,199,237 males and 49,451, 476 females at above 15 years of age (MacDonald, Wong, \& Sheldon, 2015). Despite the huge population, it is disheartening to know that Nigerian women are under-represented in both democratic and corporate governance. For instance, only $7 \%$ of seats are held by women in the national parliament (World Bank Report, 2014) and 28\% of ministerial positions are filled by women (Inter-Parliamentary Union \& UN Women, 2014). This is in spite of the various commitments undertaken by the government at international, regional and national levels. Examples of such commitments include the 35\% women's affirmative action on government organisation. The country also saw the review of the national gender policy and its strategic implementation in July 2014, the endorsement of the Beijing Declaration and Platform for Action (BDPA) that provides for affirmative action policy, Nigerian Economic Empowerment and Development Strategy (NEEDS) and Goal 3 of the Millennium Development Goals (MDG) on gender equality and women's empowerment (Choji, 2014). The MDG Goal 3 is intended at achieving gender equality and women's empowerment to foster the attainment of other MDGs. For example, achieving environmental sustainability, which is also one of the MDG goals, helps to identify the roles that gender play in the depletion and pollution of natural resources as well as the environment, particularly, the constraints and the competition in the access to and the use of natural resources. Nonetheless, developmental policies in Nigeria have been gender-biased because $70 \%$ of Nigerians living below the national poverty line are women and this makes women more vulnerable to poverty than men (Pwanagba, 2013). Consequently, a high percentage of employment of women is restricted to low income-generating activities, which are concentrated within the lower levels of the unregulated and informal sector; while men are employed in the informal sectors that are located at the upper levels, or in other words, higher income-generating activities (CIDA Nigeria \& GSAA, 2006). As in other male dominated societies, the social inter-relations and activities of Nigerian women and men are governed by patriarchal systems of socialization and cultural practices that favour the interests of men above those of women. However, regardless of gender related policies, gender diversity on corporate boards is still limited. In addition, the impact of gender diversity on the corporate board, including its effects on corporate outcomes, is not well understood in Nigeria. 


\section{Theoretical Discussion}

Quite a number of theoretical models have addressed the impact of gender-based diversity on various corporate outcomes. Among these theoretical models are the agency theory, resource dependence theory, upper echelon theory and the critical mass theory. According to the agency theory, boards of directors play an important role for the mitigation of principal to agent problems through their monitoring function (Fama \& Jensen, 1983; Jensen \& Meckling, 1976). Their monitoring function helps to enhance the optimistic behaviour of the management and align the interests of shareholders with that of the principal, which subsequently affect the performance of the company (Fama \& Jensen, 1983; Hermalin \& Weisbach, 2003). However, some aspects of the board that serve as effective monitoring mechanisms, are dependent on the extent to which the board is diverse in terms of gender diversity, or the presence of female representation on the board. This is because gender diversity enhances the effectiveness of the board of directors and adds value to the company in a tangible manner (Adams, Haan, Terjesen, \& Ees, 2015; Langevoort, 2011). Gender diversity also facilitates creativity as well as enhances the functioning and the efficiency of both the board and its committees (Adams et al., 2015).

On the other hand, the critical mass theory views that it is not only the presence of female representation on board that matters; what matters most is the number or the proportion of women on the board (Kanter, 1977). The theory suggests that a meaningful impact of gender diversity on company performance or on improving the value for shareholders can only be felt when the percentage of women is $35 \%$, which signals the critical mass of women on the board. In contrast, Schwartz-Ziv (2013) argued that the board is most active when the board has a dual critical mass (gender-balance), i.e., when the board comprises, for instance, three men and three women. This is what is meant by 'dual critical mass'.

Meanwhile, the resource dependence theory by Pfeffer (1972); and Pfeffer and Salancik (1978), which has its roots in sociological literature, proposes that the success and the survival of a company is dependent on the resources available in its external environment. The board of directors is the primary connector between a company and its external environment in obtaining the resources needed for the company's success and survival. These crucial resources can be improved through an increase in size and diversity of the board (Pfeffer, 1972; Pfeffer \& Salancik, 1978). A diverse board provides more alternative solutions to problems due to different beliefs, experiences and perspectives of those on the board (Hillman, Shropshire, \& Cannella, 2007). For instance, women have the potential to link a company to different constituencies and they are more committed than men. They also can create a better link between the company and the customers than men, which subsequently improves the sales of the company. Moreover, women serve as a role model for individuals within the company and as a mentor for aspiring women employees. Women also evaluate resource dependence differently from men and have been found to offer positive and unique contributions to the company (Peterson \& Philpot, 2007).

Lastly, the upper echelon theory, which was developed by Hambrick and Mason (1984), suggests that corporate outcomes are largely influenced by top management characteristics. 
An important measure of the role of the top management team (TMT) is gender diversity (Krishnan \& Park, 2005; Krishnan, 2009). According to the upper echelon theory, diversity in the TMT of companies may have positive impact on corporate outcomes because women possess certain unique personal characteristics compared to men. For instance, women's leadership style encourages more effective communication, deliberation and broader discussion that can enhance board effectiveness; in addition, women are known to be stricter in their monitoring function (Adams \& Ferreira, 2009). In a nutshell, the aforementioned theories have provided a clear relationship between gender diversity and various corporate outcomes that boards and corporate executives can adopt in managing a company.

\section{Literature Review}

It has been widely acknowledged that gender-based differences play a significant role, not only in leadership styles, but also in communication skills, risk behaviour and various decision-making tasks of the board. These differences have potential implications for corporate governance effectiveness, financing decisions and financial performance. Given these differences, several studies have examined if these gender-based differences have a meaningful impact on various corporate outcomes.

In general, one of the most common corporate outcomes is the company's financial performance, as several studies have considered this as a significant measure of a company's success. Some examples of such measures include, return on equity, return on assets, return on sales, return on invested capital, net profit margin and Tobin's Q, among others. These outcomes, however, may be largely affected by agency problems, i.e., a situation whereby managers may act against the best interests of shareholders in making corporate decisions. Carrying out actions against the interests of the shareholders may derail the performance of the company, as well as the value for the shareholders. One way to prevent this is by enhancing the monitoring capacity of the corporate board (Fama \& Jensen, 1983), including higher female representation on the board. Prior empirical studies have indicated that female representation on the corporate board enhances the monitoring function of the board by ensuring that the management acts in the best interests of shareholders (Adams \& Ferreira, 2009; Campbell \& Minguez-Vera, 2008). Although a gender-diverse board is beneficial, it also has some cost implications (Adams et al., 2015; Nguyen et al., 2015). The benefit has to do with the positive effect on performance, which improves the value for shareholders, while the cost is vice versa.

Several empirical studies have revealed a positive relationship between a gender-diverse board and company performance. For example, Joy, Carter, Wagner, and Narayanan (2007) discovered a strong and positive relationship between the proportion of female directors on the corporate board and the company's financial performance among a sample of fortune 500 companies. They indicated that companies with higher number of women on board have stronger financial performance than companies with lesser number of women on board. Similar results were also reported by Carter, Simkins, and Simpson (2003); Carter, D'Souza, Simkins, and Simpson (2007); and Campbell and Minguez-Vera (2008), for a sample of fortune 500 and 1,000 companies, as well as Spanish companies. In addition, Schwartz-Ziv (2013); and 
Joecks, Pull, and Vetter (2013) found that the presence of a critical mass, i.e., when at least three or more women directors $(30 \%)$ are on board, is associated with better performance for a sample of Israeli Government Business Companies (GBC) and German companies.

Additionally, a comprehensive study of 3,876 multinational public listed companies from 45 countries by Terjesen, Couto, and Francisco (2015) documented that boards with greater proportion of female directors display better financial performance. Similarly, Arena, Cirillo, Mussolino, Pulcinelli, Saggese, and Sarto (2015) found that critical mass, rather than the simple presence of female directors, has incremental benefits on company performance among a sample of 211 European Union public listed companies in the construction industry from 28 different countries. Reguera-Alvarado et al. (2015) identified that the increase in the number women on the board positively affected the financial performance of 125 public listed companies on the Madrid Stock Exchange over the period of 2005 to 2009. They concluded that compulsory legislation of female representation on corporate boards is a signal of good corporate governance.

In transitional economies, such as Hong Kong, South Korea, Malaysia, Singapore and Vietnam, Nguyen et al. (2015); and Low, Roberts, and Whiting (2015), revealed that gender diversity has a significant and positive impact on company performance. Nguyen et al. (2015) found that the performance is stronger when there is an increase in the number of female directors on the board. Results also showed that as soon as the increase reaches a break-even point of $20 \%$, the positive effect ceases. In contrast, Low, Roberts, and Whiting (2015) discovered that the positive relationship between increased number of female directors on the board and company performance in five Asian countries diminishes in countries with higher rate of female empowerment and economic participation. Besides, by employing a panel of over 2,000 Chinese listed companies from 1999 to 2011, Liu, Wei, and Xie (2014) found that gender diversity has a positive influence on company performance. In particular, female executives indicate stronger positive influence on company performance than female independent directors. Therefore, they concluded that the need for women on corporate boards is more than just for the monitoring role. Furthermore, they discovered that boards with three or more female directors show stronger positive impact on company performance than those with two or fewer female directors. In fact, other studies (e.g., Krishnan \& Park, 2005; Smith, Smith, \& Verner, 2006) have also documented that female representation and their proportion on the TMT are positively associated with company performance. While Krishnan and Park (2005) used a sample of fortune 500 companies, Smith et al. (2006) covered a sample of 2,500 Danish companies over the period of 1993 to 2001. Gender diversity has been found to be not only sensitive to shareholders, but also to other stakeholders of the company. Gupta, Lam, Sami, and Zhou (2014) found that a gender-diverse board enhances the dimensions of social, environmental and governance aspects of a company, and not just financial performance.

Furthermore, although women are known to contribute to improving board performance (Farrell and Hersch, 2005; Schwartz-Ziv, 2013), what goes on in the board meetings may be different from what goes on in the equities market. Using a panel data of 400 large US companies from 1997 to 2006, Dobbin and Jung (2011) found that block holders react 
positively to board diversity. Therefore, they proposed that gender diversity may influence performance not through the monitoring capabilities or board efficacy, but rather by activating bias on the part of institutional investors. Based on this argument, the results show that gender bias, i.e., the appointment of female directors, negatively affects stock price. On the contrary, Talijaard, Ward, and Muller (2014) presented that a gender-diverse board had a positive impact on share price performance for a sample of 40 largest companies on the Johannesburg Stock Exchange between the periods of 2000 to 2013.

Apart from that, gender diversity can also result in an increase in cost of decision- making, as well as the likelihood of faction and conflict within the team, which may affect the financial performance of a company (Adams et al., 2015). Darmadi (2013) found that the presence of female top executives is negatively related to performance measurement for a sample of Indonesian companies. However, the author states that the generalizability of the result may be difficult because the focus of the study was only a single year. Joecks, Pull, and Vetter (2013) revealed that the presence of female directors on the board had a significant and negative impact on company performance among a sample of 151 German companies over the period of 2000 to 2005. In addition, Adams and Ferreira (2009) determined that a negative relationship exists between board gender diversity and company performance in the US, partially attributed to the over-monitoring role by female directors. Besides, Ahern and Dittmar (2012) found that imposing a quota of $40 \%$ of female directors on boards in Norwegian public listed companies resulted in lower firm value. Therefore, they attributed their findings to the fact that this law forces firms to comply with the female quota.

Khalife and Chalouhi (2013); and Alowaihan (2004) determined that the causes for the gross revenue of female-owned companies to be lower than that of male-owned companies in Kuwait and Lebanon are due to liability of market newness suffered by female executives and lack of business experience. Nevertheless, other studies have documented that gender diversity is unrelated to a company's financial performance (Gallego-Álvarez, García-Sánchez, \& Rodríguez-Dominguez, 2010; Rose, 2007). It should also be noted that it is not only gender diversity that matters, but also the quality of women on the corporate board. For instance, Pucheta-Martınez and Bel-Oms (2014) discovered that the presence of independent female directors with academic degrees on the nomination and compensation committees reduces the gender wage gap. This suggests that future studies should also consider the quality of women on the board of directors.

Furthermore, literature on psychology indicates that women have better communication skills and tend to perform better in terms of problem-solving and decision making (Dallas, 2002; Schubert, 2006). In line with this claim, one would expect that female CEOs exhibit better performance than male CEOs or chairmen. For example, Peni (2012) determined that companies with female CEOs/Chair outperform male-led companies, which is an indication that the presence of female CEOs/Chair has a significantly positive impact on a company's financial performance. In fact, some of the behavioural characteristics of women, such as their risk averseness and conservatism on certain issues, can affect the company's legitimacy, corporate bank capital ratio and default risk. Moreover, empirical evidence from the US retail industry and S\&P's 1,500 companies has revealed that the presence of women on the TMT 
and board, as well as female CEOs, is negatively associated with legal and company risks (Bao, Fainshmidt, Nair, \& Vracheva 2014; Faccio, Marchica, \& Mura, 2015; Peltomaki, Swidler, \& Vahama, 2015). Similarly, Palvia, Vahama, and Vahama (2014) justified the conservativeness and the risk-averse nature among women directors. They found that US commercial banks with female CEOs hold a more conservative level of capital after controlling for bank asset risk and other attributes.

Consequently, women also tend to try as much as possible to stay out of trouble. Adhikari, Agrawal, and Malm (2015) used hand-collected data on corporate lawsuits to examine the effect of women on the TMT pertaining to corporate litigation. They asserted that companies with higher percentage of women on the TMT attract fewer lawsuits, especially in the area of product, environmental and medical liability, labour and contract. In another related study, Palvia et al. (2014) also discovered that gender diversity is relevant when a company is faced with financial distress or during a crisis because smaller banks with female CEO/Chairpersons are less likely to fail. Similarly, Strom, Espallier, and Mersland (2014) found that micro-finance institutions managed by female CEOs and chairpersons displayed better performance than their male counterparts. Moreover, with plant-level US data, Tate and Yang (2014) revealed that companies managed by female CEOs cultivate more women-friendly culture, which increases the outcome of CEOs and results in smaller wage gaps between the genders. In addition, the increase in the number of women on the corporate board influences various corporate decisions, such as fewer employee layoffs, higher labour cost and lower profit. This also has led to replacement of CEOs during poor financial performance (Schwartz-Ziv, 2013).

In corporate finance literature, mergers and acquisitions are also a crucial corporate decision where gender-related behavioural traits may be very important in the board room because male executives are likely to be more overconfident than female executives (Huang \& Kisgen, 2013; Levi et al., 2014). Besides, empirical evidence by Huang and Kisgen (2013) on US companies has documented that male executives are relatively overconfident compared to female executives, especially when concerning decisions related to acquisition and debt issues. In particular, they identified that men executives undertake more acquisition and debt issues than female executives. In fact, companies managed by female executives grow more slowly and are less likely to make acquisitions. However, announcement returns on acquisition and debt issues made by female executives are higher than that of male executives. In addition, earnings forecasts made by female executives have significantly wider bands than male executives. Levi et al. (2014) examined the impact of the presence of women on corporate boards pertaining to acquisitions, as well as the financial terms of acquisition in terms of bid premium paid. They found that companies with more women directors are less acquisitive than companies with fewer women directors, the economic interpretation being that the presence of women on the board reduces acquisition frequency by $8 \%$. In addition, bidders with women directors on the acquisition board are negatively associated with the size of bid premium. Further details show that they are also associated with lower bid premium at $15 \%$ compared to bidders with exclusively men directors. These justify that women directors 
have less confidence in the precision of their estimation on acquisition and their expected value of acquisitions.

In addition, the structure of a company's capital is another important financing decision. Faccio, Marchica, and Mura (2015) asserted that companies managed by female CEOs are associated with less volatile earnings, lower leverage, and higher chance of survival, compared to companies managed by male CEOs. Additionally, Harris (2014) examined the relationship between corporate leverage and gender diversity for a sample of fortune 500 US public listed companies over the period of 2012 to 2013. The author classified the sample into companies with no women on board and companies with $25 \%$ of women directors on board. The results indicated that gender diversity for a company with $25 \%$ of women on board has a direct significantly negative relationship with corporate leverage, as well as a moderating effect between board age and size on corporate leverage.

In addition, it is well-acknowledged that men and women behave somewhat differently in terms of decision making, cognitive functioning and ethical behaviour, which may have important implications on financial reporting quality (Peni \& Vahamaa, 2010). Furthermore, women are known to be less corrupt and more dedicated to their duties (Gender Report, 2012). Thus, gender diversity creates a more transparent and informative environment because women tend to be more concerned with interpersonal relationships and rules conformity. For instance, Thiruvadi and Huang (2011) suggested that the presence of female directors on the audit committee can affect management decisions and audit quality. Empirical evidence presented by Capezio and Mavisakalyan (2015), after examining the relationship between proportion of women on the corporate board and cases of fraud among 128 Australian listed companies, revealed that higher percentage of women representation on corporate boards reduces the probability of fraud. Since women are known to be strict and ethically-oriented, a gender-diverse board can also help in reducing earnings management practices. A study by Arun, Almahrog, and Aribi (2015) showed that UK companies with higher number of independent female directors on the corporate board, have reduced earnings management practices. On top of that, Kyaw, Olugbode, and Petracci (2015) also presented similar result among European countries with high gender equality.

In addition, Thiruvadi and Huang (2011) found that the presence of female directors is associated with income decreasing earnings management among a sample of 320 S\&P Small Cap companies. Similarly, Niskanen, Karjalainen, Karjalainen, and Niskanen (2012) documented differences in cosmetic earnings management between companies audited by male auditors and female auditors among private Small and Medium Enterprises (SMEs) in Finland. They found that companies audited by male auditors engage in more cosmetic earnings management compared to those audited by female auditors. Also, Ittonen, Vähämaa, and Vähämaa (2013) investigated Finnish and Swedish listed companies and revealed that companies with female audit engagement partners are associated with small abnormal accruals. Peni and Vahamaa (2010) also showed that companies with CFOs are associated with income decreasing discretionary accruals, which indicate that female executives engage in conservative earnings management strategies. 
In contrast, they did not find any relationship between CEOs' gender and earnings management practices. Another study by Upadhyay and Zeng (2014) that employed the herfindahl index for gender and ethnic diversities on board to examine their impact on corporate opacity measured as share turnover, analysts forecast error and bid-and-ask spread, found that gender and ethnic diversities are negatively associated with corporate opacity. However, the use of herfindahl index is somewhat confusing because it considers a board with higher proportion of ethnic and women directors as a less diverse group. In contrast, Ye, Zhang, and Rezaee's (2010) study that covered Chinese companies showed that the gender of top executive members is unrelated to earnings quality, proxied by earnings persistence, accuracy of current earnings in forecasting future cash flows, absolute magnitude of discretionary accruals and association between earnings and stock returns. A study by Hili and Affes (2012) on 70 French companies listed on the SBF 120 Index indicated that gender diversity is unrelated to earnings persistence. This review further confirms that gender diversity has multifaceted roles on various corporate outcomes, such as both financial and non-financial performances of a company, corporate risk taking, financial reporting quality, improved audit quality and committee activities.

\section{Conclusion}

This review demonstrates that gender diversity matters for various corporate outcomes, such as financial performance, market reaction, survival, corporate risk taking, corporate financing decisions and financial reporting quality. However, the detailed comprehension on the association between gender-based diversity and these corporate outcomes still remains unclear. In fact, empirical evidence on this aspect has been entirely skewed to developed countries with only a few studies in transitional economies, leaving the frontier markets unexplored. However, most frontier markets are immature and are characterised by a less developed external corporate governance mechanism. In fact, the results from a frontier market, like Nigeria, is worth studying, especially in considering the differences in culture, language, economic development, legal system and personal values, as well as the importance of female directors and executives on the corporate board. Indeed, there is a need to conduct more empirical studies on this area. Moreover, the results from this frontier market can also enhance other empirical results from the developed market. This is because women are well-known to be friendlier than men, better in monitoring, exhibit more frequency in board meetings, are more conservative, less confident, risk-averse and also less corrupt than men.

\section{References}

Adams, R. B., \& Ferreira, D. (2009). Women in the boardroom and their impact on governance and performance. Journal of Financial Economics, 94(2), 291-309. http://dx.doi.org/10.1016/j.jfineco.2008.10.007

Adams, R. B., Haan, J., Terjesen, S., \& Ees, H. (2015). Board diversity: Moving the field forward. Corporate Governance: An International Review, 23(2), 77-82. http://dx.doi.org/10.1111/corg.12106 
Adams, R. B., \& Funk, P. (2012). Beyond the glass ceiling: Does gender matter?. Management Science, 58(2), 219-235. http://dx.doi.org/10.1287/mnsc.1110.1452

Adhikari, B. K., Agrawal, A., \& Malm, J. (2015). Do Women Stay Out of Trouble? Evidence from Corporate Litigation. Evidence from Corporate Litigation (July 7, 2015). http://bama.ua.edu/ aagrawal/Women_Litigation.pdf

Ahern, K. R., \& Dittmar, A. K. (2012). The changing of the boards: The impact on firm valuation of mandated female board representation. Quarterly Journal of Economics, 127(1), 137-197. http://dx.doi.org/10.2139/ssrn.1364470

Arena, C., Cirillo, A., Mussolino, D., Pulcinelli, I., Saggese, S., \& Sarto, F. (2015). Women on board: evidence from a masculine industry. Corporate Governance: The International Journal of Business in Society, 15(3). http://dx.doi.org/10.1108/CG-02-2014-0015

Alowaihan, A. K. (2004). Gender and business performance of Kuwait small firms: A comparative approach. International Journal of Commerce and Management, 14(3/4), 69-82. http://dx.doi.org/10.1108/10569210480000185

Arun, T. G., Almahrog, Y. E., \& Aribi, Z. A. (2015). Female directors and earnings management: Evidence from UK companies. International Review of Financial Analysis, 39, 137-146. http://dx.doi.org/10.1016/j.irfa.2015.03.002

Bao, S., Fainshmidt, S., Nair, A., \& Vracheva, V. (2014). Women in Upper Echelons of Management, Tenure and Legal Risk. British Journal of Management, 25(2), 388-405. http://dx.doi.org/10.1111/j.1467-8551.2012.00847

Bertrand, M., \& Hallock, K. F. (2001). The gender gap in top corporate jobs. Industrial \& Labor Relations Review, 55(1), 3-21. http://dx.doi.org/ 10.1177/001979390105500101

Campbell, K., \& Mínguez-Vera, A. (2008). Gender diversity in the boardroom and firm financial performance. Journal of Business Ethics, 83(3), 435-451. http://dx.doi.org/10.1007/s10551-007-9630-y

Capezio, A., \& Mavisakalyan, A. (2015). Women in the boardroom and fraud: Evidence from Australia. Australian Journal of Management, July 23, 2015, http://dx.doi.org/10.1177/0312896215579463

Carter, D. A., Simkins, B. J., \& Simpson, W. G. (2003). Corporate governance, board diversity, and firm value. Financial review, 38(1), 33-53. http://dx.doi.org/10.1111/1540-6288.00034

Carter, D., D'Souza, F. P., Simkins, B. J., \& Simpson, W. G. (2007). The diversity of corporate board committees and firm financial performance. http://dx.doi.org/10.2139/ssrn.972763

Choji, R. (May 11, 2014) http://leadership.ng/news/370291/nigerian-women-achieved-35-affirmative-action-maina

Dallas, L. (2002). The new managerialism and diversity on corporate boards of directors. Tulane Law Review, 76(5-6), 1363-1405. heinonline.org 


\section{Macrothink Institute ${ }^{\text {TM }}$}

Darmadi, S. (2013). Do women in top management affect firm performance? Evidence from Indonesia. Corporate Governance: The international journal of business in society, 13(3), 288-304. http://dx.doi.org/10.1108/CG-12-2010-0096

Dobbin, F., \& Jung, J. (2011). Corporate board gender diversity and stock performance: The competence gap or institutional investor bias?. North Carolina Law Review, 89. ssrn.com/abstract $=2410911$

Edward, P., Angaye, G., Gwilliam, D. (2008). Corporate governance in infancy and growth an interview-based study of the development of governance and corporate regulation in Nigeria. Research in Accounting in Emerging Economies, 8, 359 - 407.

Faccio, M., Marchica, M. T., \& Mura, R. (2014). CEO gender and corporate risk-taking. http://dx.doi.org//10.2139/ssrn.2021136

Fama, E. F., \& Jensen, M. C. (1983), Separation of ownership and control. Journal of Law and Economics, 26(2), 301-325.

Ferreira, D. (2015). Board Diversity: Should We Trust Research to Inform Policy?. Corporate Governance: An International Review, 23(2), 108-111. http://dx.doi.org/10.1111/corg.12092

Ferreira, F., \& Gyourko, J. (2014). Does gender matter for political leadership? The case of US $\begin{array}{lllll}\text { mayors. Journal of Public } & \text { Economics, } & \text { 112, }\end{array}$ http://dx.doi.org/10.1016/j.jpubeco.2014.01.006

Farrell, K. A., \& Hersch, P. L. (2005). Additions to corporate boards: the effect of gender. Journal of Corporate finance, 11(1), 85-106. http://dx.doi.org/10.1016/j.jcorpfin.2003.12.001

Gallego-Álvarez, I., García-Sánchez, I. M., \& Rodríguez-Dominguez, L. (2010). The influence of gender diversity on corporate performance. Revista de Contabilidad, 13(1), 53-88. http://dx.doi.org/10.1016/S1138-4891(10)70012-1

Gamba, M., \& Goldstein, A. (2009). The gender dimension of business elites: Italian women directors since 1934. Journal of Modern Italian Studies, 14(2), 199-225. http://dx.doi.org/abs/10.1080/13545710902826469

Gender Situation Assessment and Analysis (GSAA) 2006. http://www.aacoalition.org/national_policy_women.htm

Gender in Nigeria Report. (2012). Improving the Lives of Girls and Women in Nigeria. www.gov.uk/government/uploads/.../Gender-Nigeria2012.pdf

Goergen, M., \& Renneboog, L. (2014). Inside the board room. Journal of Corporate Finance, 26, 1-5. http://dx.doi.org/10.1016/j.jcorpfin.2014.05.004

Gupta, P. P., Lam, K. C., Sami, H., \& Zhou, H. (2014). Board Diversity and its Effect on Firm Financial and Non-Financial Performance. Available at SSRN. Available at SSRN: http://ssrn.com.sci-hub.org/abstract $=2531212$ 
Harris, C. K. (2014) Women director on public: Does a critical mass affect leverage? Peer Reviewed

http://www.nabet.us/proceedings-archive/NABET-ProceedingsFinal-2014.pdf

Hermalin, B. E., \& Weisbach, M. S. (2003). Boards of Directors as an Endogenously Determined Institution: A Survey of the Economic Literature (Digest Summary). Economic Policy Review, 9(17-26). http://dx.doi.org/abs/10.2469/dig.v34.n1.1410

Hili, W., \& Affess, H. (2012). Corporate boards gender diversity and earnings persistence: The case of French listed firms. Global Journal of Management And Business Research, 12(22).

Hillman, A. J., Shropshire, C., \& Cannella, A. A. (2007). Organizational predictors of women on corporate boards. Academy of Management Journal, 50(4), 941-952. http://dx.doi.org/10.5465/AMJ.2007.26279222

Huang, J., \& Kisgen, D. J. (2013). Gender and corporate finance: Are male executives overconfident relative to female executives?. Journal of Financial Economics, 108(3), 822-839. http://dx.doi.org/10.1016/j.jfineco.2012.12.005

Ittonen, K., Vähämaa, E., \& Vähämaa, S. (2013). Female auditors and accruals quality. Accounting Horizons, 27(2), 205-228. http://dx.doi.org/10.2308/acch-50400

Jensen, M. C., \& Meckling, W. H. (1976). Theory of the firm: Managerial behavior, agency costs and ownership structure. Journal of Financial Economics, 3(4), 305-360. http://dx.doi.org/10.1016/0304-405X(76)90026-X

Joecks, J., Pull, K., \& Vetter, K. (2013). Gender diversity in the boardroom and firm performance: What exactly constitutes a “critical mass?". Journal of business ethics, 118(1), 61-72. http://dx.doi.org/10.1007/s10551-012-1553-6

Joy, L., Carter, N. M., Wagner, H. M., \& Narayanan, S. (2007). The bottom line: Corporate performance and women's representation on boards. Catalyst, 3.

Johnson, S. G., Schnatterly, K., \& Hill, A. D. (2012). Board composition beyond independence social capital, human capital, and demographics. Journal of Management, http://dx.doi.org/10.1177/0149206312463938

Kanter, R. M. (1977). Some effects of proportions on group life: Skewed sex ratios and responses to token women. American journal of Sociology, 965-990. http://dx.doi.org/10.1177/0149206312463938

Khalife, D., \& Chalouhi, A. (2013). Gender and business performance. International Strategic Management Review, 1(1), 1-10.http://dx.doi.org/10.1016/j.ism.2013.08.001

Krishnan, H. A., \& Park, D. (2005). A few good women-on top management teams. Journal of Business Research, 58(12), 1712-1720. http://dx.doi.org/10.1016/j.jbusres.2004.09.003

Krishnan, H. A. (2009). What causes turnover among women on top management teams?. $\begin{array}{llll}\text { Journal of Business Research, 62(11), } & \text { 1181-1186. }\end{array}$ http://dx.doi.org/10.1016/j.jbusres.2008.09.001 
Kyaw, K., Olugbode, M., \& Petracci, B. (2015). Does Gender Diverse Board Mean Less Earnings Management?. Finance Research Letters, 14, 135-141 http://dx.doi.org/10.1016/j.frl.2015.05.006

Langevoort, D. C. (2010). Commentary: Puzzles about corporate boards and board diversity. NCL Rev., 89, 841. http://heinonline.org/HOL/LandingPage?handle=hein.journals/nclr89\&di

Levi, M., Li, K., \& Zhang, F. (2014). Director gender and mergers and acquisitions. Journal of Corporate Finance, 28, 185-200. http://dx.doi.org/10.1016/j.jcorpfin.2013.11.005

Liu, Y., Wei, Z., \& Xie, F. (2014). Do women directors improve firm performance in China?. Journal of Corporate Finance, 28, 169-184. http://dx.doi.org/10.1016/j.jcorpfin.2013.11.016

Low, D. C., Roberts, H., \& Whiting, R. H. (2015). Board gender diversity and firm performance: Empirical evidence from Hong Kong, South Korea, Malaysia and Singapore. Pacific-Basin Finance Journal. http://dx.doi.org/10.1016/j.pacfin.2015.02.008

MacDonald, E., Wong, R., \& Sheldon, D. (2015). Gender Profile: Nigeria. http://oasis.col.org/handle/11599/920

Matsa, D. A., \& Miller, A. R. (2011). Chipping away at the glass ceiling: Gender spillovers in corporate leadership. http://dx.doi.org/10.2139/ssrn.1799575

Mohan, N. (2014). A review of the gender effect on pay, corporate performance and entry into top management. International Review of Economics \& Finance, 34, 41-51. http://dx.doi.org/10.1016/j.iref.2014.06.005

Niskanen, J., Karjalainen, J., Karjalainen, J., \& Niskanen, M. (2012). Earnings cosmetics and auditor gender: evidence from Finnish private firms. International Journal of Behavioural Accounting and Finance, 3(3-4), 188-201. http://dx.doi.org/ 10.1504/ijbaf.2012.052175

Nguyen, T., Locke, S., \& Reddy, K. (2015). Does boardroom gender diversity matter? Evidence from a transitional economy. International Review of Economics \& Finance, 37, 184-202. http://dx.doi.org/10.1016/j.iref.2014.11.022

Palvia, A., Vahamaa, E., \& Vahamaa, S. (2014). Are female CEOs and Chairwomen more conservative and risk averse? Evidence from the banking industry during the financial crisis. Journal of Business Ethics, 1-18. http://dx.doi.org/10.1007/s10551-014-2288-3

Peltomäki, J., Swidler, S., \& Vähämaa, S. (2015). Age, Gender, and Risk-Taking: Evidence from the S\&P 1500 Executives and Firm Riskiness. http://dx.doi.org//10.2139/ssrn.2547516

Peni, E., \& Vähämaa, S. (2010). Female executives and earnings management. Managerial Finance, 36(7), 629-645. http://dx.doi.org//10.1108/03074351011050343

Peni, E. (2014). CEO and Chairperson characteristics and firm performance. Journal of Management \& Governance, 18(1), 185-205. http://dx.doi.org/10.1007/s10997-012-9224-7 
Peterson, C. A., \& Philpot, J. (2007). Women's roles on US Fortune 500 boards: Director expertise and committee memberships. Journal of Business Ethics, 72(2), 177-196. http://dx.doi.org/10.1007/s10551-006-9164-8

Pfeffer, J. (1972). Size and composition of corporate boards of directors: The organization and its environment. Administrative Science Quarterly, 218-228.

Pfeffer, J., \& Salancik, G. R. (2003). The external control of organizations: A resource dependence perspective. Stanford University Press.

Post, C., \& Byron, K. (2014). Women on boards and firm financial performance: A meta-analysis. Academy of Management Journal. http://dx.doi.org/ 10.5465/amj.2013.0319.

Pucheta-Martínez, M. C., \& Bel-Oms, I. (2014). The gender gap in pay in company boards. Industrial and Corporate Change, 1-44. http://dx.doi.org/ 10.1093/icc/dtu016

Pwanagba, A. (2013, July 13). "70\% of Nigerian women are living below poverty line". Daily Post Nigeria. Retrieved from http://dailypost.ng/2013/07/13/70-of-nigerian-women-are-living-below-povertyline-minister/

Reguera-Alvarado, N., de Fuentes, P., \& Laffarga, J. (2015). Does Board Gender Diversity Influence Financial Performance? Evidence from Spain. Journal of Business Ethics, 1-14. http://dx.doi.org/10.1007/s10551-015-2735-9

Rose, C. (2007). Does female board representation influence firm performance? The Danish evidence. Corporate Governance: An International Review, 15(2), 404-413. http://dx.doi.org/10.1111/j.1467-8683.2007.00570.x

Schwartz-Ziv, M. (2013). Does the gender of directors matter?. http://dx.doi.org//10.2139/ssrn.1868033

Seierstad, C., Warner-Søderholm, G., Torchia, M., \& Huse, M. (2015). Increasing the Number of Women on Boards: The Role of Actors and Processes. Journal of Business Ethics, 1-27. http://dx.doi.org/10.1007/s10551-015-2715-0

Sherwin, L. (2015). More women on corporate boards "is just common sense" Why it makes good business sense to have women in leadership positions http://www.ebrd.com/pages/news/press/2014/140508.shtml

Schubert, R. (2006). Analyzing and managing risks - on the importance of gender difference in risk attitudes. Managerial Finance, 32(9), 706-715. http://dx.doi.org//10.1108/03074350610681925

Smith, S. C., \& Rothbaum, J. (2013). Cooperatives in a Global Economy: Key Economic Issues, Recent Trends, and Potential for Development (No. 68). IZA Policy Paper. http://hdl.handle.net/10419/91777

Strom, R. O., D’Espallier, B., \& Mersland, R. (2014). Female leadership, performance, and governance in microfinance institutions. Journal of Banking \& Finance, 42, 60-75. http://dx.doi.org/10.1016/j.jbankfin.2014.01.014 


\section{Macrothink}

Asian Journal of Finance \& Accounting

ISSN 1946-052X

2015, Vol. 7, No. 2

Smith, N., Smith, V., \& Verner, M. (2006). Do women in top management affect firm performance? A panel study of 2,500 Danish firms. International Journal of Productivity and Performance Management, 55(7), 569-593. http://dx.doi.org//10.1108/17410400610702160

Taljaard, C. C., Ward, M., \& Muller, C. (2014). Board Diversity and Financial Performance: A Graphical Time-Series Approach. http://dx.doi.org//10.2139/ssrn.2399343

Tate, G., \& Yang, L. (2014). Female leadership and gender equity: Evidence from plant closure. Journal of Financial Economics, 117, 77-97. http://dx.doi.org/10.1016/j.jfineco.2014.01.004

Terjesen, S., Couto, E. B., \& Francisco, P. M. (2015). Does the presence of independent and female directors impact firm performance? A multi-country study of board diversity. Journal of Management \& Governance, 1-37. http://dx.doi.org/10.1007/s10997-014-9307-8

Thiruvadi, S., \& Huang, H. W. (2011). Audit committee gender differences and earnings management. Gender in Management: An International Journal, 26(7), 483-498. http://dx.doi.org/10.1108/17542411111175469

Upadhyay, A., \& Zeng, H. (2014). Gender and ethnic diversity on boards and corporate information environment. Journal of Business Research, 67(11), 2456-2463. http://dx.doi.org/10.1016/j.jbusres.2014.03.005

World Bank. (2014). Proportion of women holding seats in national parliament. Retrieved from http://data.worldbank.org/indicator/SG.GEN.PARL.ZS

Ye, K., Zhang, R., \& Rezaee, Z. (2010). Does top executive gender diversity affect earnings quality? A large sample analysis of Chinese listed firms. Advances in Accounting, 26(1), 47-54. http://dx.doi.org/10.1016/j.adiac.2010.02.008

Zelechowski, D. D., \& Bilimoria, D. (2004). Characteristics of women and men corporate inside directors in the US. Corporate Governance: An International Review, 12(3), 337-342. http://ssrn.com/abstract $=557315$ 